\title{
DIGITALCOMMONS
}

\section{Association among obesity-related anthropometric phenotypes: Analyzing genetic and environmental contribution}

\author{
Aline Jelenkovic \\ Department of Genetics, Physical Anthropology and Animal Physiology, Faculty of Science and Technology, University of the \\ Basque Country, Apdo 644, Bilbao 48080, Spain, aline.jelenkovic@ehu.es \\ Esther Rebato \\ Department of Genetics, Physical Anthropology and Animal Physiology, Faculty of Science and Technology, University of the \\ Basque Country, Apdo 644, Bilbao 48080, Spain, esther.rebato@ehu.es
}

\section{Recommended Citation}

Open access pre-print, subsequently published as Jelenkovic, Aline and Rebato, Esther (2012) "Association among Obesity-Related Anthropometric Phenotypes: Analyzing Genetic and Environmental Contribution," Human Biology: Vol. 84: Iss. 2, Article 2.

Available at: http://digitalcommons.wayne.edu/humbiol_preprints/5 


\section{Title}

Association among obesity-related anthropometric phenotypes: Analyzing genetic and environmental contribution

\section{Running title}

Genetic association between obesity phenotypes

\section{Authors' names}

Aline Jelenkovic, Esther Rebato

\section{Authors'affiliations}

Aline Jelenkovic, Department of Genetics, Physical Anthropology and Animal

Physiology, Faculty of Science and Technology, University of the Basque Country, Apdo 644, Bilbao 48080, Spain.

Tel: +34 94 6015405; fax: +34 94601 3145; e-mail: aline.jelenkovic@ehu.es

Esther Rebato, Department of Genetics, Physical Anthropology and Animal Physiology, Faculty of Science and Technology, University of the Basque Country, Apdo 644, Bilbao 48080, Spain.

Tel: +34 94 6012601; fax: +34 94601 3145; e-mail: $\underline{\underline{\text { esther.rebato@ehu.es }}}$

\section{Keywords}

Anthropometry, common genetic and environmental factors, body mass, body fat, fat distribution, nuclear families, obesity 


\section{ABSTRACT}

Obesity has become a public health and policy problem in many parts of the world. Epidemiological and population studies in this field are usually based on different anthropometric measures, however, common genetic and environmental factors between these phenotypes have been scarcely studied. The objective of this work is to assess the strength of these factors on the covariation among a large set of obesity-related traits. The subject group consisted of 533 nuclear families living in the Greater Bilbao (Spain), and included 1702 individuals aged 2-61 years. Detailed anthropometric measurements (stature, breadths, circumferences and skinfolds) were carried out in each subject. Bivariate quantitative genetic analyses were performed using a variance components procedure implemented in the software SOLAR. The results revealed that the majority of these traits is affected by common genetic and environmental factors. All correlations were significantly different from 1 and varied from non-significant to very high $(>0.90$, $\mathrm{P}<0.0001$ ), with clearly lower pleiotropic effects among pairs including fat distribution traits. Despite the strong common genetic effects detected among phenotypes determining the amount of body fat and mass, there is a residual genetic influence on the local fatness measures that cannot be explained exclusively by the genetic influence on overall fatness. Moreover, the observed relationships confirm a partially different genetic control of truncal and peripheral fat. In conclusion, our findings highlight the relevance of considering different types of traits in the prevention and treatment of obesity, as well as in the search for genes involved in its development. 
Obesity has emerged as one of the most serious public health concerns of the $21^{\text {st }}$ century due to its increasing prevalence in the adult and children population worldwide (WHO). Although obesity rates in the United States are among the highest in the world, during the last years many industrialized countries have experienced similar increases, with Spain at the head of the European countries in terms of childhood overweight and obesity (IASO). The current progression is particularly alarming since obesity is associated with an increased risk of numerous adverse health outcomes such as cardiovascular disease, type 2 diabetes, osteoarthritis and some cancers (Yusuf et al., 2004; Kushner and Blatner, 2005; Schienkiewitz et al., 2006; Reeves et al., 2007).

Epidemiological studies have shown that apart from the amount of body fat, its distribution (adiposity of generalized fatness, excess of subcutaneous fat at trunkabdominal level, excess of abdominal visceral fatness and excess of gluteo-femoral fatness) has different impact on health (Bouchard et al., 1990; Janssen et al., 2004; Snijder et al., 2004; Park et al., 2009). Reliable methods for measurement of body fat and fat distribution are therefore of substantial importance. Sophisticated techniques such as X-ray absorptiometry (DEXA), computed tomography (CT) and magnetic resonance imaging (MRI) (Veldhuis et al., 2005; Lee and Gallagher, 2008) have been developed, however, these methods are expensive and impractical for field- or large population-based studies. Measurements of anthropometric variables are simple, inexpensive and non-invasive methods for indirect assessment of body composition and fat distribution (Yusuf et al., 2004). Although the relationship between overweight and/or obesity and its associated risks factors in clinical and epidemiological field is primarily based on body mass index (BMI), other studies also include traits such as the waist circumference, waist to hip ratio (WHR) and the sum of some skinfolds, 
nevertheless, more complex phenotypes are required to integrate information from different parts of the body. For example, factors extracted from a factor analysis could represent features that contain a higher degree of genetic variance than the original variables separately (Hauspie et al., 1985) and Heath-Carter somatotype (Carter and Heath, 1990), provides a more generalized approach to body types and summarizes body shape in three basic components: endomorphy, mesomorphy and ectomorphy (fatness and leanness, musculoskeletal development for the individual's height and linearity related component, respectively).

Body fat mass and distribution are determined by multiple environmental and genetic factors. Given the complex nature of obesity in terms of phenotype definition, it can be expected that the different phenotypes exhibits different biology and hence may have different genetic and environmental determination. Large family studies in different populations have consistently showed heritabilities ranging from around 0.3 to 0.6 for obesity-related traits (e.g. Butte et al., 2006; Bastarrachea et al., 2007; Zillikens et al., 2008; Mathias et al., 2009; Jelenkovic et al., 2011). However, there is a limited number of studies examining whether genes and residual environment influencing one trait have an effect on other traits, and the majority of them analysed only a few associations (Comuzzie et al., 1994; Choh et al., 2001; Bastarrachea et al., 2007; Benyamin et al., 2007; Hasselbalch et al., 2008; Mathias et al., 2009). The mechanism of these contributions is thus still poorly understood and quantification of the strength of common genetic factors among phenotypes is critically important to address the genetic basis for obesity. Accordingly, the purpose of the present study was to determine the contribution of genetic and environmental factors on the covariation among a large set of obesity-related phenotypes in nuclear families from the Greater Bilbao. 


\section{MATERIALS AND METHODS}

Participants

The sample recruitment and structure have been described elsewhere (Jelenkovic et al., 2011). Briefly, the present cross-sectional study was conducted on 533 nuclear families composed of 346 fathers (29.8-61.2 years), 509 mothers (26.0-57.2 years), 445 sons (2.0-19.5 years) and 402 daughters (2.0-18.3 years). The data collection was carried out in 22 education centres of the Greater Bilbao (Spain), during two academic years (20062007 and 2007-2008). This sample forms part of an urban population of medium-high socioeconomic level; around half of the parental generation $(53 \%$ and $42 \%$ of fathers and mothers, respectively) had a high-level occupation and are university educated ( $47 \%$ and $56 \%$, respectively). The prevalence of overweight and obesity was $51.9 \%$ and $12 \%, 20.4 \%$ and $4.6 \%, 21.1 \%$ and $1.6 \%, 19.9 \%$ and $1.7 \%$ in men, women, boys and girls, respectively. Greater Bilbao is a comarca of Biscay (Basque Country, Spain), which is considered to be the main economic area of the Basque Country and one of the most important of Spain. Only Caucasian individuals who presented a European origin were included in the study. The project was approved by the ethics committee of the University of the Basque Country. Permission to carry out the study in the education centres was asked from the Basque Government, and also from the direction of each centre. Written informed consent was obtained from all study participants.

Measurements 
Anthropometric measures included stature, weight, two breadths (humerus and femoral), five circumferences (upper arm relaxed, upper arm contracted, waist, hip, calf) and six skinfold thicknesses (biceps, triceps, subscapular, suprailiac, abdominal, calf). All measures were taken by the same investigator (A.J.) for the whole sample following standard anthropometric techniques (Lohman et al., 1988). Skinfolds were measured using a Lange caliper (Cambridge Scientific Industries, Cambridge, MD). Circumferences were taken to the nearest $\mathrm{mm}$ by using Harpenden anthropometric tape (Holtain Ltd) and the other measurements with Siber-Hegner instruments (GPM, Zurich, Switzerland) accurate to $1 \mathrm{~mm}$. A digital balance to the nearest $0.1 \mathrm{~kg}$ was used to measure body weight. From these anthropometric measures five derived variables were calculated: the sum of truncal (SK3T) and extremities (SK3E) skinfolds, body mass index $\left[\mathrm{BMI}=\right.$ weight $(\mathrm{kg}) /$ height $\left.\left(\mathrm{m}^{2}\right)\right]$, the waist to hip ratio $[\mathrm{WHR}=$ waist circumference/hip circumference] and the trunk to extremity skinfolds ratio [TER = $($ suprailiac + subscapular + abdominal $) /($ calf + biceps + triceps $)]$. Next, the three components of the Heath-Carter's anthropometric somatotype were calculated according to formulae described in Carter and Heath (1990).

Statistical analysis

All statistical computations were carried out using SPSS package version 17.0 for Windows (SPSS Inc., Chicago, IL, USA). First, two factor analyses were computed, regardless of sex and age, for the two categories of anthropometric traits (circumferences and skinfolds) using the principal components extraction method. The eigenvalue of 1 criterion was implemented to retain the factors. Next, a stepwise regression analysis was used to remove the effects of age (age, age ${ }^{2}$ and age ${ }^{3}$, within 
each generation and sex for all the studied anthropometric traits. Phenotypes were then generated for each individual by retaining the residual regression score and then standardizing to a mean of 0 and a variance of 1 within each group. According to Blangero et al. (2001), when the normality assumption did not hold for a specific trait ( $\mathrm{k}$ >2) after adjustment for significant covariates, natural log-transformation was applied followed by a new data assessment.

Quantitative genetic analysis

Narrow sense or additive heritabilities $\left(h^{2}\right)$ for anthropometric phenotypes were calculated using the variance-components method implemented in Sequential Oligogenic Linkage Analysis Routines (SOLAR 4.2.7 available online at: http://www. sfbr.org/solar/; (Almasy and Blangero, 1998)). This method distinguishes between the additive genetic $\left(\mathrm{V}_{\mathrm{G}}\right)$ and environmental $\left(\mathrm{V}_{\mathrm{E}}\right)$ components that form the total variation of the trait $\left(\mathrm{V}_{\mathrm{P}}\right): \mathrm{V}_{\mathrm{P}}=\mathrm{V}_{\mathrm{G}}+\mathrm{V}_{\mathrm{E}}$. The portion of the total phenotypic variance accounted for by the additive genetic variance is denoted by narrow sense heritability $\left(h^{2}\right): h^{2}=\mathrm{V}_{\mathrm{G}}$ / $\mathrm{V}_{\mathrm{P}}$. The environmental component includes environmental factors, the non-additive genetic component, and measurement errors. Parameters estimation was performed by restricted maximum likelihood methods. In the process, the null hypothesis, in which the additive genetic variance $\left(\mathrm{V}_{\mathrm{G}}\right)$ equals zero, was tested against an alternative hypothesis in which the additive genetic variance was estimated. Minus two times the difference in the log likelihood between the two models is distributed as a $1 / 2$ chi-square statistic with 1 degree of freedom. 
Bivariate genetic analysis (also implemented in SOLAR) is the extension from univariate genetic analysis and was conducted to partition the total phenotypic correlations $\left(\rho_{\mathrm{P}}\right)$ between the pairs of traits into genetic $\left(\rho_{\mathrm{G}}\right)$ and environmental correlations $\left(\rho_{\mathrm{E}}\right): \rho_{\mathrm{P}}=\rho_{\mathrm{G}} \sqrt{ }\left(h^{2}{ }_{1} \mathrm{~h}^{2}{ }_{2}\right)+\rho_{\mathrm{E}} \sqrt{ }\left(\left(1-h^{2}{ }_{1}\right)\left(1-h^{2}{ }_{2}\right)\right)$. In this equation, $h^{2}{ }_{1}$ and $h^{2}{ }_{2}$ are the heritabilities of trait 1 and trait 2 , respectively. The bivariate phenotype is modeled as a linear function of the individual's phenotypic values, the population means, the additive genetic values, and environmental effects. The significance of $\rho_{\mathrm{G}}$ and $\rho_{\mathrm{E}}$ was calculated by comparison of the log-likelihood of a more restricted model in which the same parameter is set to zero. To test if covariation between traits was entirely due to shared genes (i.e., complete pleiotropy), the significance of $\rho_{\mathrm{G}}$ differing from 1 was also evaluated.

\section{RESULTS}

Preliminary statistical analysis

Since descriptive statistics for these anthropometric measurements and derived variables have been previously published (Jelenkovic et al., 2011), only those for the sums of skinfolds are shown in Table 1. Due to the wide range of ages included in the offspring generation $($ mean $=9.02,8.92 ; \mathrm{SD}=3.85,3.85$ for boys and girls, respectively), results for sons and daughters are not presented. Briefly, adult males showed greater means for all traits defining body mass (e.g. weight, circumferences, BMI, mesomorphy) and for the truncal skinfolds, whereas women presented considerably more subcutaneous fat in the extremities, and were more ectomorphic. Regarding factor analysis, a single factor was retained for each set of measures, which explained about 93.9\% (CRsF) and $73.5 \%$ 
$(\mathrm{SKsF})$ of the total variation in the sets of traits, respectively. The high load scores obtained suggest that CRsF can be interpreted as a measure of overall body mass and SKsF as an indicator of the amount of subcutaneous fat. These two synthetic traits were used as summary variables in the quantitative genetic analysis.

Quantitative genetic analysis

The univariate variance component analysis $\left(h^{2}\right)$ for the sums of skinfolds (after accounting for age and sex effects) is shown in Table 1. According to the results for the single skinfolds in Jelenkovic et al. (2011), SK3E presented a higher heritability than SK3T. Inspection of Table 2 showed that genetic $\left(\rho_{\mathrm{G}}\right)$ and environmental $\left(\rho_{\mathrm{E}}\right)$ correlations calculated among these phenotypes ranged from non-significant to strong values and were higher within similar traits. As can be seen, with the exception of some pairs formed by fat distribution indices, the majority of pairs exhibited common genetic and/or environmental factors. Although the general trend is towards a similar pattern of genetic and environmental correlations, some differences are detected in their relative magnitude among groups of measures and also for some specific traits. For example, mean genetic correlation is greater than the environmental $\left(\rho_{\mathrm{G}}>\rho_{\mathrm{E}}\right)$ among circumferences, whereas more similar values $\left(\rho_{\mathrm{G}} \sim \rho_{\mathrm{E}}\right)$ were observed among skinfolds and those phenotypes that summarize the amount of body mass and fat (BMI and SK factors and endomorphy). Finally, genetic associations for fat distribution indices, mesomorphy and ectomorphy were, in general, lower $\left(\rho_{\mathrm{E}}>\rho_{\mathrm{G}}\right)$.

\section{DISCUSSION}


Faced with the current epidemic of obesity, the comprehension of the mechanisms by which obesity is manifest is of substantial relevance. The existing relationship among deposition of fat at different sites provides an insight into body architecture in relation to this component. To the best of our knowledge, this is the first comprehensive analysis that includes a large set of simple and derived variables and thus provides a global perspective of human body integration. Although direct comparisons of the magnitude of correlations between traits across studies are problematic (since they depend on study design, methods of parameter estimation, type of correlation estimated, among others), the general findings of this work follow those of earlier studies.

Significant genetic correlation among obesity phenotypes suggests that they are regulated, wholly or in part, by the same genes (pleiotropy) or by closely spaced genes (coincident linkage) (Almasy et al., 1997). The high genetic and environmental correlations detected among weight, waist and hip circumference and BMI in the present investigation were similar to those found in extended pedigrees (Bastarrachea et al., 2007; Mathias et al., 2009) and in twins for women (Hasselbalch et al., 2008), but in contrast to the observations of Mathias et al. (2009) we did not found complete pleiotropy between BMI and waist circumference. Apart from other phenotypes normally analysed, skinfolds thickness is an economic and simple indirect measure of adiposity that can be accurately used in epidemiological studies. Pleiotropic effects between triceps and subscapular skinfolds were slightly lower than those for Mexican Americans (Comuzzie et al., 1994), and considerably lower than for Samoans (Choh et al., 2001). Of particular interest is that there appears to be a hierarchy of common effects on this combination of skinfolds measures, that is, whereas common environmental factors remained fairly constant between all skinfolds, pleiotropic effects 
were greater for the pairs formed by skinfolds from the same anatomical region (e.g. biceps-triceps and abdominal-suprailiac) and lower between those of the trunk and extremities (e.g. calf-subscapular and calf-abdominal). Accordingly, whereas environmental correlations for BMI-SK3T and BMI-SK3E are very similar $(0.83$ and 0.79), genetic associations presented greater differences (0.82 and 0.60$)$. These observations indicate that although common genetic factors act in a different way depending on the location of the subcutaneous fat, all skinfolds present a global or generalized responsiveness to environmental factors, which was also observed in Mexican Americans (Comuzzie et al., 1994).

Non-significant to small common genetic and environmental factors were found to affect the association between fat distribution indices and the majority of adiposity traits. Some differences were also observed between both traits, that is, whereas WHR did not show evidence of pleiotropy with the majority of adiposity traits, TER presented more significance in the genetic associations and was environmentally correlated with all phenotypes. In contrast to the observations of other authors (Cardon et al., 1994; Zabaneh et al., 2009), who found a significant genetic relationship for BMI-WHR (0.44 and 0.52 , respectively), the covariation between overall obesity and the abdominal distribution of fat was not mediated by common genetic factors in the Greater Bilbao population. As have been previously detected, this discrepancy between the results is probably caused, at least in part, by the wide range of ages that makes up our sample. To our knowledge, no published study refers to shared additive and environmental effects of somatotype components and only phenotypic correlations are available for comparison. As reported by Bale (1980), the majority of studies of correlations between somatotype components have focussed on body fat and lean body weight. The obtained 
phenotypic correlations with weight in the Greater Bilbao sample $(0.67,0.48,-0.63$ for endomorphy, mesomorphy and ectomorphy, respectively) were similar to those from women physical education students $(0.73,0.40,-0.65)$ (Bale, 1980), suggesting a constant pattern across populations. On the other hand, our findings are in agreement with those of Yeong et al. (1997) who determined good correlations for somatotype drawing and BMI, weight, waist and hip circumference, but a relatively lower correlation for WHR. In addition, some authors have suggested that WHR is not appropriate for the measurement of body fat mass distribution for its lack of correlation with CT (Keller et al., 1999) and the marginal correlations observed with any of the DEXA measurements (Ketel et al., 2007). Therefore, the weak correlation obtained for the pairs form by WHR in this work, summed to the findings of other studies suggest that no decisive conclusions can be drawn when WHR is the only indicator of fat distribution considered in a specific investigation.

Strong genetic and environmental relationships have been observed between those phenotypes that account for the amount of body mass and those of body fat (those including skinfolds). The consistent association between traits that differ in their composition and orientation (circumferences-skinfolds, BMI-SKsF, endomorphymesomorphy) agrees with the extended idea that the increase in body mass reflects the increase in the amount of fat (in untrained individuals). However, the different information that provides each type of variables highlights the interest of considering the amount of adipose tissue, and not only the total body mass, in the prevention and treatment of obesity. 
The current investigation reports interesting findings on the genetic and environmental architecture of human body morphology and composition but also presents some potential limitations. First, correlation estimates could be affected by observer error. However, since all measures were taken by the same person the inter-observer measurement error is non-existent, which reduces considerably the total error. On the other hand, a potential error to take into account in studies based on multiple comparisons is the type I error. In the present investigation all phenotypes showed kurtosis $<2.0$ and therefore, estimates should not be affected by this error in a determinant way (Blangero et al., 2001).

In conclusion, our findings reaffirm that there exist strong common genetic factors for all obesity-related traits determining the amount of body fat and mass, but also that there is a residual genetic influence on the local fatness measures that cannot be explained exclusively by the genetic influence on overall fatness. The different genetic control of the phenotypes accounting for truncal and peripheral fat mass highlights the relevance of considering both types of phenotypes in the search prevention and treatment of obesity. Understanding the core of the genetic relationships between phenotypes will help gain insights into the complex nature of obesity and the identification of the genes responsible. Moreover, pleiotropic effects should be taken into account, for their potential implications, whenever these phenotypes of generalized or regional adiposity are considered as risk factors for the development of particular diseases. Future perspectives related to the current topic are to determine if the proportion of the variance of these phenotypes explained by genetic factors, as well as the strength of common genetic and environmental factors among them, are affected by biodemographic factors and socioeconomic status (SES). It is well established that the 
variation of body morphology and composition is under genetic control, however, environmental factors have also shown a deterministic role, with their relative contribution probably varying by context. Although in the literature a large number of familial factors have been associated with the physical development of children, the effects of environmental factors (e.g. SES) on heritability estimates and genetic and environmental correlations of anthropometric traits have been scarcely investigated in human populations.

\section{ACKNOWLEDGMENTS}

This study was supported jointly by a biannual grant of the University of the Basque Country (UPV05/12, 2005-2007). AJ was supported by a predoctoral grant from the Ministry of Education of Spain (AP-2005-236). We would like to thank the many education centres who allowed us to carry out the study. Special thanks also go to the families enrolled in the study for their enthusiastic participation.

\section{LITERATURE CITED}

Almasy L., Blangero J. 1998. Multipoint quantitative-trait linkage analysis in general pedigrees. Am J Hum Genet 62(5):1198-211.

Bale P. 1980. The relationship of physique and body composition to strenght in a group of physical education students. Brit J Sports Med 14(4):193-198.

Bastarrachea R.A., Kent J.W., Jr., Rozada G., Cole S.A., Lopez-Alvarenga J.C., Aradillas C. et al. 2007. Heritability and genetic correlations of metabolic 
disease-related phenotypes in Mexico: preliminary report from the GEMM Family Study. Hum Biol 79(1):121-9.

Benyamin B., Sorensen T.I., Schousboe K., Fenger M., Visscher P.M., Kyvik K.O. 2007. Are there common genetic and environmental factors behind the endophenotypes associated with the metabolic syndrome? Diabetologia 50(9):1880-8.

Blangero J., Williams J.T., Almasy L. 2001. Variance component methods for detecting complex trait loci. Adv Genet 42:151-81.

Bouchard C., Bray G.A., Hubbard V.S. 1990. Basic and clinical aspects of regional fat distribution. Am J Clin Nutr 52(5):946-50.

Butte N.F., Cai G., Cole S.A., Comuzzie A.G. 2006. Viva la Familia Study: genetic and environmental contributions to childhood obesity and its comorbidities in the Hispanic population. Am J Clin Nutr 84(3):646-54; quiz 673-4.

Cardon L.R., Carmelli D., Fabsitz R.R., Reed T. 1994. Genetic and environmental correlations between obesity and body fat distribution in adult male twins. Hum Biol 66(3):465-79.

Carter J.E.L., Heath B.H. 1990. Somatotyping-development and applications. Cambridge [England] ; New York: Cambridge University Press. xiv, 503 p. p.

Comuzzie A.G., Blangero J., Mahaney M.C., Mitchell B.D., Stern M.P., MacCluer J.W. 1994. Genetic and environmental correlations among skinfold measures. Int J Obes Relat Metab Disord 18(6):413-8.

Choh A.C., Gage T.B., McGarvey S.T., Comuzzie A.G. 2001. Genetic and environmental correlations between various anthropometric and blood pressure traits among adult Samoans. Am J Phys Anthropol 115(4):304-11. 
Hasselbalch A.L., Benyamin B., Visscher P.M., Heitmann B.L., Kyvik K.O., Sorensen T.I. 2008. Common genetic components of obesity traits and serum leptin. Obesity (Silver Spring) 16(12):2723-9.

Hauspie R.C., Susanne C., Defrise-Gussenhoven E. 1985. Testing for the presence of genetic variance in factors of face measurements of Belgian twins. Ann Hum Biol 12(5):429-40.

International Association for the Study of Obesity (IASO). In: International Obesity TaskForce Prevalence Data. $\underline{\text { http://www.iotf.org/database/index.asp. }}$ Accessed 2011.

Janssen I., Katzmarzyk P.T., Ross R. 2004. Waist circumference and not body mass index explains obesity-related health risk. Am J Clin Nutr 79(3):379-84.

Jelenkovic A., Poveda A., Rebato E. 2011. Quantitative genetics of human morphology and obesity-related phenotypes in nuclear families from the Greater Bilbao (Spain): Comparison with other populations. Ann Hum Biol 38(4):471-8.

Jeong Y.S., Park E.W., Bae J.M., Lee Y. 1997. Correlation of somatotype drawing and anthropometric values. J Korean Acad Fam Med 18(9):918-926.

Keller C., Chintapalli K., Lancaster J. 1999. Correlation of anthropometry with CT in Mexican-American women. Res Nurs Health 22(2):145-53.

Ketel I.J., Volman M.N., Seidell J.C., Stehouwer C.D., Twisk J.W., Lambalk C.B. 2007. Superiority of skinfold measurements and waist over waist-to-hip ratio for determination of body fat distribution in a population-based cohort of Caucasian Dutch adults. Eur J Endocrinol 156(6):655-61.

Kushner R.F., Blatner D.J. 2005. Risk assessment of the overweight and obese patient. $J$ Am Diet Assoc 105(5 Suppl 1):S53-62. 
Lee S.Y., Gallagher D. 2008. Assessment methods in human body composition. Curr Opin Clin Nutr Metab Care 11(5):566-72.

Lohman T.G., Roche A.F., Martorell R., editors. 1988. Anthropometric standardization reference manual Champaign, Illinois: Human Kinetics Books.

Mathias R.A., Deepa M., Deepa R., Wilson A.F., Mohan V. 2009. Heritability of quantitative traits associated with type 2 diabetes mellitus in large multiplex families from South India. Metabolism 58(10):1439-45.

Park S.H., Choi S.J., Lee K.S., Park H.Y. 2009. Waist circumference and waist-toheight ratio as predictors of cardiovascular disease risk in Korean adults. Circ J 73(9):1643-50.

Reeves G.K., Pirie K., Beral V., Green J., Spencer E., Bull D. 2007. Cancer incidence and mortality in relation to body mass index in the Million Women Study: cohort study. Bmj 335(7630):1134.

Schienkiewitz A., Schulze M.B., Hoffmann K., Kroke A., Boeing H. 2006. Body mass index history and risk of type 2 diabetes: results from the European Prospective Investigation into Cancer and Nutrition (EPIC)-Potsdam Study. Am J Clin Nutr 84(2):427-33.

Snijder M.B., Zimmet P.Z., Visser M., Dekker J.M., Seidell J.C., Shaw J.E. 2004. Independent and opposite associations of waist and hip circumferences with diabetes, hypertension and dyslipidemia: the AusDiab Study. Int J Obes Relat Metab Disord 28(3):402-9.

Veldhuis J.D., Roemmich J.N., Richmond E.J., Rogol A.D., Lovejoy J.C., SheffieldMoore M. et al. 2005. Endocrine control of body composition in infancy, childhood, and puberty. Endocr Rev 26(1):114-46. 
World Health Organization (WHO). http://www.who.int/topics/obesity/en. Accessed 2011.

Yusuf S., Hawken S., Ounpuu S., Dans T., Avezum A., Lanas F. et al. 2004. Effect of potentially modifiable risk factors associated with myocardial infarction in 52 countries (the INTERHEART study): case-control study. Lancet 364(9438):93752.

Zabaneh D., Chambers J.C., Elliott P., Scott J., Balding D.J., Kooner J.S. 2009. Heritability and genetic correlations of insulin resistance and component phenotypes in Asian Indian families using a multivariate analysis. Diabetologia $52(12): 2585-9$.

Zillikens M.C., Yazdanpanah M., Pardo L.M., Rivadeneira F., Aulchenko Y.S., Oostra B.A. et al. 2008. Sex-specific genetic effects influence variation in body composition. Diabetologia 51(12):2233-41. 
Table 1. Descriptive statistics and narrow sense heritability estimates $\left(h^{2}\right)$ of sum of skinfolds for the parental generation

\begin{tabular}{lllc}
\hline Phenotypes & Fathers & Mothers & ${\text { Heritability } \pm \text { S.E. }^{a}}$ \\
\hline SK3T $(\mathrm{mm})$ & $78.9(23.7)$ & $64.4(25.5)$ & $0.36 \pm 0.05$ \\
SK3E (mm) & $38.2(14.3)$ & $60.7(19.0)$ & $0.47 \pm 0.05$
\end{tabular}

Descriptive statistics in mean (standard deviation). S.E., Standard error; SK3T, Sum of truncal skinfolds; SK3E, Sum of extremity skinfolds. ${ }^{\text {a } H e r i t a b i l i t y ~ e s t i m a t e s ~ w e r e ~ s i g n i f i c a n t ~ a t ~ l e v e l ~}$ $P<0.0001$. 
Table 2. Genetic (upper triangle) and environmental (lower triangle) correlation matrices among the studied phenotypes

\begin{tabular}{|c|c|c|c|c|c|c|c|c|c|c|c|c|c|c|c|c|c|c|c|c|c|c|}
\hline & 1 & 2 & 3 & 4 & 5 & 6 & 7 & 8 & 9 & 10 & 11 & 12 & 13 & 14 & 15 & 16 & 17 & 18 & 19 & 20 & 21 & 22 \\
\hline 1 Stature & & $.70^{\mathrm{a}}$ & $.27^{\mathrm{b}}$ & $.36^{\mathrm{a}}$ & $.53^{\mathrm{a}}$ & $.46^{\mathrm{a}}$ & $.41^{\mathrm{a}}$ & .12 & .11 & $.19^{\mathrm{d}}$ & $.21^{\mathrm{c}}$ & $.22^{\mathrm{c}}$ & $.18^{\mathrm{c}}$ & $.21^{\mathrm{c}}$ & $.14^{\mathrm{d}}$ & $.18^{\mathrm{d}}$ & .12 & $-.28^{\mathrm{b}}$ & $.16^{\mathrm{d}}$ & .07 & $-.31^{\mathrm{a}}$ & $.27^{\mathrm{a}}$ \\
\hline 2 Weight & $.48^{\mathrm{a}}$ & & $.82^{\mathrm{a}}$ & $.84^{\mathrm{a}}$ & $.94^{\mathrm{a}}$ & $.86^{\mathrm{a}}$ & $.92^{\mathrm{a}}$ & $.60^{\mathrm{a}}$ & $.58^{\mathrm{a}}$ & $.63^{\mathrm{a}}$ & $.70^{\mathrm{a}}$ & $.69^{\mathrm{a}}$ & $.56^{\mathrm{a}}$ & $.71^{\mathrm{a}}$ & $.61^{\mathrm{a}}$ & $.69^{\mathrm{a}}$ & $.80^{\mathrm{a}}$ & -.11 & $.29^{\mathrm{b}}$ & $.62^{\mathrm{a}}$ & $.34^{\mathrm{a}}$ &.$-49^{\mathrm{a}}$ \\
\hline 3 Upper arm C & $.25^{\mathrm{b}}$ & $.85^{\mathrm{a}}$ & & $.82^{\mathrm{a}}$ & $.84^{\mathrm{a}}$ & $.78^{\mathrm{a}}$ & $.96^{\mathrm{a}}$ & $.72^{\mathrm{a}}$ & $.72^{\mathrm{a}}$ & $.68^{\mathrm{a}}$ & $.78^{\mathrm{a}}$ & $.74^{\mathrm{a}}$ & $.58^{\mathrm{a}}$ & $.78^{\mathrm{a}}$ & $.71^{\mathrm{a}}$ & $.72^{\mathrm{a}}$ & $.92^{\mathrm{a}}$ & .06 & $.21^{\mathrm{d}}$ & $.77^{\mathrm{a}}$ & $.64^{\mathrm{a}}$ & $-.76^{\mathrm{a}}$ \\
\hline 4 Waist $\mathrm{C}$ & $.25^{\mathrm{b}}$ & $.87^{\mathrm{a}}$ & $.75^{\mathrm{a}}$ & & $.85^{\mathrm{a}}$ & $.70^{\mathrm{a}}$ & $.90^{\mathrm{a}}$ & $.67^{\mathrm{a}}$ & $.60^{\mathrm{a}}$ & $.76^{\mathrm{a}}$ & $.82^{\mathrm{a}}$ & $.85^{\mathrm{a}}$ & $.50^{\mathrm{a}}$ & $.80^{\mathrm{a}}$ & $.62^{\mathrm{a}}$ & $.84^{\mathrm{a}}$ & $.87^{\mathrm{a}}$ & $.40^{\mathrm{b}}$ & $.44^{\mathrm{a}}$ & $.77^{\mathrm{a}}$ & $.46^{\mathrm{a}}$ & $-.66^{\mathrm{a}}$ \\
\hline 5 Hip C & $.46^{\mathrm{a}}$ & $.90^{\mathrm{a}}$ & $.78^{\mathrm{a}}$ & $.78^{\mathrm{a}}$ & & $.80^{\mathrm{a}}$ & $.93^{\mathrm{a}}$ & $.69^{\mathrm{a}}$ & $.63^{\mathrm{a}}$ & $.70^{\mathrm{a}}$ & $.78^{\mathrm{a}}$ & $.76^{\mathrm{a}}$ & $.60^{\mathrm{a}}$ & $.79^{\mathrm{a}}$ & $.67^{\mathrm{a}}$ & $.76^{\mathrm{a}}$ & $.85^{\mathrm{a}}$ & -.18 & $.32^{\mathrm{a}}$ & $.72^{\mathrm{a}}$ & $.41^{\mathrm{a}}$ & $-.58^{\mathrm{a}}$ \\
\hline 6 Calf $\mathrm{C}$ & $.40^{\mathrm{a}}$ & $.80^{\mathrm{a}}$ & $.68^{\mathrm{a}}$ & $.65^{\mathrm{a}}$ & $.76^{\mathrm{a}}$ & & $.87^{\mathrm{a}}$ & $.51^{\mathrm{a}}$ & $.50^{\mathrm{a}}$ & $.47^{\mathrm{a}}$ & $.54^{\mathrm{a}}$ & $.51^{\mathrm{a}}$ & $.58^{\mathrm{a}}$ & $.53^{\mathrm{a}}$ & $.55^{\mathrm{a}}$ & $.57^{\mathrm{a}}$ & $.79^{\mathrm{a}}$ & -.13 & .08 & $.50^{\mathrm{a}}$ & $.58^{\mathrm{a}}$ & $-.64^{\mathrm{a}}$ \\
\hline $7 \mathrm{CRsF}$ & $.34^{\mathrm{a}}$ & $.95^{\mathrm{a}}$ & $.93^{\mathrm{a}}$ & $.87^{\mathrm{a}}$ & $.90^{\mathrm{a}}$ & $.82^{\mathrm{a}}$ & & $.70^{\mathrm{a}}$ & $.67^{\mathrm{a}}$ & $.71^{\mathrm{a}}$ & $.79^{\mathrm{a}}$ & $.76^{\mathrm{a}}$ & $.59^{\mathrm{a}}$ & $.80^{\mathrm{a}}$ & $.69^{\mathrm{a}}$ & $.78^{\mathrm{a}}$ & $.93^{\mathrm{a}}$ & .05 & $.29^{\mathrm{c}}$ & $.75^{\mathrm{a}}$ & $.60^{\mathrm{a}}$ & $-.70^{\mathrm{a}}$ \\
\hline 8 Biceps SK & $.16^{\mathrm{d}}$ & $.69^{\mathrm{a}}$ & $.75^{\mathrm{a}}$ & $.69^{\mathrm{a}}$ & $.65^{\mathrm{a}}$ & $.58^{\mathrm{a}}$ & $.76^{\mathrm{a}}$ & & $.92^{\mathrm{a}}$ & $.68^{\mathrm{a}}$ & $.79^{\mathrm{a}}$ & $.78^{\mathrm{a}}$ & $.73^{\mathrm{a}}$ & $.80^{\mathrm{a}}$ & $.92^{\mathrm{a}}$ & $.93^{\mathrm{a}}$ & $.72^{\mathrm{a}}$ & .16 & -.11 & $.89^{\mathrm{a}}$ & $.38^{\mathrm{a}}$ & $-.60^{\mathrm{a}}$ \\
\hline 9 Triceps SK & .11 & $.65^{\mathrm{a}}$ & $.72^{\mathrm{a}}$ & $.61^{\mathrm{a}}$ & $.68^{\mathrm{a}}$ & $.59^{\mathrm{a}}$ & $.72^{\mathrm{a}}$ & $.80^{\mathrm{a}}$ & & $.65^{\mathrm{a}}$ & $.75^{\mathrm{a}}$ & $.73^{\mathrm{a}}$ & $.83^{\mathrm{a}}$ & $.75^{\mathrm{a}}$ & $.97^{\mathrm{a}}$ & $.93^{\mathrm{a}}$ & $.69^{\mathrm{a}}$ & .06 & $-.22^{\mathrm{d}}$ & $.89^{\mathrm{a}}$ & $.35^{\mathrm{a}}$ & $-.58^{\mathrm{a}}$ \\
\hline 10 Subscapular SK & $.14^{\mathrm{d}}$ & $.73^{\mathrm{a}}$ & $.75^{\mathrm{a}}$ & $.74^{\mathrm{a}}$ & $.69^{\mathrm{a}}$ & $.59^{\mathrm{a}}$ & $.77^{\mathrm{a}}$ & $.77^{\mathrm{a}}$ & $.73^{\mathrm{a}}$ & & $.77^{\mathrm{a}}$ & $.78^{\mathrm{a}}$ & $.42^{\mathrm{a}}$ & $.89^{\mathrm{a}}$ & $.61^{\mathrm{a}}$ & $.79^{\mathrm{a}}$ & $.71^{\mathrm{a}}$ & $.23^{\mathrm{d}}$ & $.46^{\mathrm{a}}$ & $.87^{\mathrm{a}}$ & $.30^{\mathrm{b}}$ & $-.54^{\mathrm{a}}$ \\
\hline 11 Suprailiac SK & .08 & $.70^{\mathrm{a}}$ & $.72^{\mathrm{a}}$ & $.75^{\mathrm{a}}$ & $.65^{\mathrm{a}}$ & $.56^{\mathrm{a}}$ & $.74^{\mathrm{a}}$ & $.78^{\mathrm{a}}$ & $.74^{\mathrm{a}}$ & $.77^{\mathrm{a}}$ & & $.94^{\mathrm{a}}$ & $.65^{\mathrm{a}}$ & $.96^{\mathrm{a}}$ & $.77^{\mathrm{a}}$ & $.92^{\mathrm{a}}$ & $.81^{\mathrm{a}}$ & .18 & $.35^{\mathrm{c}}$ & $.94^{\mathrm{a}}$ & $.34^{\mathrm{b}}$ & $-.61^{\mathrm{a}}$ \\
\hline 12 Abdominal SK & .10 & $.72^{\mathrm{a}}$ & $.74^{\mathrm{a}}$ & $.73^{\mathrm{a}}$ & $.65^{\mathrm{a}}$ & $.58^{\mathrm{a}}$ & $.75^{\mathrm{a}}$ & $.79^{\mathrm{a}}$ & $.74^{\mathrm{a}}$ & $.82^{\mathrm{a}}$ & $.85^{\mathrm{a}}$ & & $.56^{\mathrm{a}}$ & $.97^{\mathrm{a}}$ & $.80^{\mathrm{a}}$ & $.84^{\mathrm{a}}$ & $.77^{\mathrm{a}}$ & $.27^{\mathrm{d}}$ & $.42^{\mathrm{b}}$ & $.90^{\mathrm{a}}$ & $.33^{\mathrm{b}}$ & $-.62^{\mathrm{a}}$ \\
\hline 13 Calf SK & .09 & $.63^{\mathrm{a}}$ & $.67^{\mathrm{a}}$ & $.62^{\mathrm{a}}$ & $.63^{\mathrm{a}}$ & $.61^{\mathrm{a}}$ & $.69^{\mathrm{a}}$ & $.73^{\mathrm{a}}$ & $.72^{\mathrm{a}}$ & $.71^{\mathrm{a}}$ & $.69^{\mathrm{a}}$ & $.75^{\mathrm{a}}$ & & $.58^{\mathrm{a}}$ & $.92^{\mathrm{a}}$ & $.82^{\mathrm{a}}$ & $.62^{\mathrm{a}}$ & -.04 & $-.39^{\mathrm{a}}$ & $.91^{\mathrm{a}}$ & $.23^{\mathrm{c}}$ & $-.50^{\mathrm{a}}$ \\
\hline $14 \mathrm{SK} 3 \mathrm{~T}$ & .11 & $.76^{\mathrm{a}}$ & $.77^{\mathrm{a}}$ & $.85^{\mathrm{a}}$ & $.70^{\mathrm{a}}$ & $.61^{\mathrm{a}}$ & $.80^{\mathrm{a}}$ & $.83^{\mathrm{a}}$ & $.78^{\mathrm{a}}$ & $.89^{\mathrm{a}}$ & $.95^{\mathrm{a}}$ & $.95^{\mathrm{a}}$ & $.75^{\mathrm{a}}$ & & $.74^{\mathrm{a}}$ & $.92^{\mathrm{a}}$ & $.82^{\mathrm{a}}$ & .23 & $.68^{\mathrm{a}}$ & $.95^{\mathrm{a}}$ & $.35^{\mathrm{a}}$ & $-.61^{\mathrm{a}}$ \\
\hline 15 SK3E & .13 & $.71^{\mathrm{a}}$ & $.77^{\mathrm{a}}$ & $.70^{\mathrm{a}}$ & $.72^{\mathrm{a}}$ & $.64^{\mathrm{a}}$ & $.79^{\mathrm{a}}$ & $.92^{\mathrm{a}}$ & $.92^{\mathrm{a}}$ & $.80^{\mathrm{a}}$ & $.80^{\mathrm{a}}$ & $.78^{\mathrm{a}}$ & $.90^{\mathrm{a}}$ & $.86^{\mathrm{a}}$ & & $.94^{\mathrm{a}}$ & $.60^{\mathrm{a}}$ & .07 & $-.27^{\mathrm{c}}$ & $.87^{\mathrm{a}}$ & $.33^{\mathrm{a}}$ & $-.59^{\mathrm{a}}$ \\
\hline $16 \mathrm{SKsF}$ & .12 & $.77^{\mathrm{a}}$ & $.79^{\mathrm{a}}$ & $.79^{\mathrm{a}}$ & $.75^{\mathrm{a}}$ & $.65^{\mathrm{a}}$ & $.83^{\mathrm{a}}$ & $.91^{\mathrm{a}}$ & $.87^{\mathrm{a}}$ & $.88^{\mathrm{a}}$ & $.91^{\mathrm{a}}$ & $.92^{\mathrm{a}}$ & $.84^{\mathrm{a}}$ & $.97^{\mathrm{a}}$ & $.96^{\mathrm{a}}$ & & $.81^{\mathrm{a}}$ & .15 & .05 & $.97^{\mathrm{a}}$ & $.36^{\mathrm{a}}$ & $-.64^{\mathrm{a}}$ \\
\hline 17 BMI & $.16^{\mathrm{d}}$ & $.92^{\mathrm{a}}$ & $.85^{\mathrm{a}}$ & $.89^{\mathrm{a}}$ & $.85^{\mathrm{a}}$ & $.77^{\mathrm{a}}$ & $.94^{\mathrm{a}}$ & $.72^{\mathrm{a}}$ & $.70^{\mathrm{a}}$ & $.77^{\mathrm{a}}$ & $.77^{\mathrm{a}}$ & $.77^{\mathrm{a}}$ & $.69^{\mathrm{a}}$ & $.83^{\mathrm{a}}$ & $.79^{\mathrm{a}}$ & $.84^{\mathrm{a}}$ & & .14 & $.27^{\mathrm{c}}$ & $.80^{\mathrm{a}}$ & $.74^{\mathrm{a}}$ & $-.89^{\mathrm{a}}$ \\
\hline 18 WHR & $-.23^{\mathrm{b}}$ & $.21^{\mathrm{b}}$ & $.15^{\mathrm{c}}$ & $.54^{\mathrm{a}}$ & -.01 & -.13 & .05 & $.16^{\mathrm{c}}$ & .06 & $.25^{\mathrm{a}}$ & $.32^{\mathrm{a}}$ & $.27^{\mathrm{a}}$ & .10 & $.33^{\mathrm{a}}$ & $.12^{\mathrm{d}}$ & $.25^{\mathrm{a}}$ & $.31^{\mathrm{a}}$ & & $.31^{\mathrm{c}}$ & $.23^{\mathrm{d}}$ & .18 & $-.24^{\mathrm{a}}$ \\
\hline
\end{tabular}




\begin{tabular}{|c|c|c|c|c|c|c|c|c|c|c|c|c|c|c|c|c|c|c|c|c|c|c|}
\hline 19 TER & .11 & $.42^{\mathrm{a}}$ & $.45^{\mathrm{a}}$ & $.48^{\mathrm{a}}$ & $.32^{\mathrm{a}}$ & $.31^{\mathrm{a}}$ & $.42^{\mathrm{a}}$ & $.33^{\mathrm{a}}$ & $.25^{\mathrm{a}}$ & $.59^{\mathrm{a}}$ & $.60^{\mathrm{a}}$ & $.63^{\mathrm{a}}$ & $.24^{\mathrm{a}}$ & $.56^{\mathrm{a}}$ & $.28^{\mathrm{a}}$ & $.47^{\mathrm{a}}$ & $.46^{\mathrm{a}}$ & $.20^{\mathrm{b}}$ & & .18 & .10 & -.16 \\
\hline 20 Endomorphy & .04 & $.73^{\mathrm{a}}$ & $.77^{\mathrm{a}}$ & $.75^{\mathrm{a}}$ & $.70^{\mathrm{a}}$ & $.60^{\mathrm{a}}$ & $.79^{\mathrm{a}}$ & $.83^{\mathrm{a}}$ & $.86^{\mathrm{a}}$ & $.93^{\mathrm{a}}$ & $.90^{\mathrm{a}}$ & $.88^{\mathrm{a}}$ & $.74^{\mathrm{a}}$ & $.95^{\mathrm{a}}$ & $.88^{\mathrm{a}}$ & $.95^{\mathrm{a}}$ & $.81^{\mathrm{a}}$ & $.25^{\mathrm{a}}$ & $.56^{\mathrm{a}}$ & & $.40^{\mathrm{a}}$ & $-.65^{\mathrm{a}}$ \\
\hline 21 Mesomorphy & .12 & $.66^{\mathrm{a}}$ & $.78^{\mathrm{a}}$ & $.63^{\mathrm{a}}$ & $.58^{\mathrm{a}}$ & $.69^{\mathrm{a}}$ & $.79^{\mathrm{a}}$ & $.57^{\mathrm{a}}$ & $.56^{\mathrm{a}}$ & $.63^{\mathrm{a}}$ & $.61^{\mathrm{a}}$ & $.62^{\mathrm{a}}$ & $.56^{\mathrm{a}}$ & $.65^{\mathrm{a}}$ & $.61^{\mathrm{a}}$ & $.66^{\mathrm{a}}$ & $.80^{\mathrm{a}}$ & $.22^{\mathrm{b}}$ & $.39^{\mathrm{a}}$ & $.67^{\mathrm{a}}$ & & $-.83^{\mathrm{a}}$ \\
\hline 22 Ectomorphy & .06 & $-.77^{\mathrm{a}}$ & $-.77^{\mathrm{a}}$ & $-.77^{\mathrm{a}}$ & $-.71^{\mathrm{a}}$ & $-.64^{\mathrm{a}}$ & $-.82^{\mathrm{a}}$ & $-.68^{\mathrm{a}}$ & $-.67^{\mathrm{a}}$ & $-.78^{\mathrm{a}}$ & $-.75^{\mathrm{a}}$ & $-.77^{\mathrm{a}}$ & $-.68^{\mathrm{a}}$ & $-.81^{\mathrm{a}}$ & $-.74^{\mathrm{a}}$ & $-.81^{\mathrm{a}}$ & $-.89^{\mathrm{a}}$ & $-.30^{\mathrm{a}}$ & $-.48^{\mathrm{a}}$ & $-.84^{\mathrm{a}}$ & $-.80^{\mathrm{a}}$ & \\
\hline
\end{tabular}

C, circumference; SK, skinfold; SK3T, Sum of truncal skinfolds; SK3E, Sum of extremity skinfolds; BMI, Body mass index; WHR, Waist to hip ratio; TER, Trunk to extremity skinfold ratio. Estimate is significant at: ${ }^{\mathrm{a}}(P<0.0001),{ }^{\mathrm{b}}(P<0.001),{ }^{\mathrm{c}}(P<0.01),{ }^{\mathrm{d}}(P<0.05)$. 